\title{
Influence of water deficit on morphological, physiological and growth of Balsa (Ochroma pyramidale)
}

\author{
PETER VERA ${ }^{1}$, MARCIA ASTORGA-ELÓ ${ }^{2}$, ROLORD SEVERE ${ }^{3}$, LAURA MORANTE ${ }^{3}$, \\ JAIME MORANTE ${ }^{4}$, JHON MONTENEGRO ${ }^{5}$, KELLY DUMORNÉ6, ${ }^{6, *}$
}

${ }^{1}$ Doctorado en Ciencias Agropecuarias, Uiniversidad Catolica de Temuco, Chile

${ }^{2}$ Carrera de Nutrición y Dietética. Facultad de Ciencias de la Salud. Universidad Autónoma de Chile

${ }^{3}$ Doctorado en Ciencias Agroalimentarias y Medioambiente, Facultad de Ciencias Agropecuarias y Forestales, Universidad de La Frontera, Temuco, Chile

${ }^{4}$ Proteómica y Genómica Funcional de Plantas Departamento, Agroquímica y Bioquímica Facultad de Ciencias-Fase II, Universidad de Alicante, San Vicente del Raspeig Alicante, Spain

${ }^{5}$ Laboratorio de Biotecnología, Departamento de Biotecnología de la Universidad Técnica Estatal de Quevedo, Quevedo, Ecuador

${ }^{6}$ Vice-rectory for Research and Postgraduate Studies, Graduate Academic Direction, University of La Frontera, Temuco, Chile

${ }^{7}$ Center of Biotechnology in Reproduction (CEBIOR-BIOREN), University of La Frontera, Temuco, Chile

\begin{abstract}
Water is one of the main factors that influence the growth and development of plants. Balsa (Ochroma pyramidale) is a fast-growing tropical tree species with a great demand in the international market. The influence of soil, water deficit on morphological, physiological, and the growth of Balsa (Ochroma pyramidale) with and without irrigation was investigated. For this study, four random repetitions were carried out in a randomized complete block design. The plants were irrigated regularly with furrow irrigation. The timing of irrigation was based on the soil, water potential, according to treatment criteria. All pots were irrigated at 15, 30, 45, 60 and 75 days. Genomic DNA of $O$. Pyramidale was identified by ERIC-PCR and RAPD, while phylogenetic tree was determined using the UPGMA method. The results showed that leave number, shoot number, stem elongation and stem diameter were affected significantly $(\mathrm{P}<0.05)$ between the plant without irrigation compared to control (with irrigation) during the days of assessment. Regarding stomata number, no significant differences $(\mathrm{P}>0.05)$ were observed, while stomata length remained high $(>20 \mu \mathrm{m})$ and stomata diameter was decreased during evaluation days in plants without irrigation compared to control. DNA of eight plants isolated showed different band profiles. In conclusion, the parameters evaluated can be used as a measure of water stress, growers should be careful when using $O$. Pyramidale in both nursery and orchards where water scarcity is present.
\end{abstract}

Keywords Ochroma pyramidale, water potential, drought, growth.

To cite this article: VERA P, ASTORGA-ELÓ M, SEVERE R, MORANTE L, MORANTE J, MONTENEGRO J, DUMORNÉ K. Influence of water deficit on morphological, physiological and growth of Balsa (Ochroma pyramidale). Rom Biotechnol Lett. 2020; 25(6): 2148-2155. DOI: $10.25083 / \mathrm{rbl} / 25.6 / 2148.2155$ 


\section{Introduction}

Balsa (Ochroma pyamidale) is a fast growing, early successional, tropical tree species characterized by very low wood density (SEABRA \& al [1]). It is a forest species that has great demand in the international market. $O$. pyamidale is cultivated naturally and by reforestation, especially in the sub-tropical jungle of Ecuador, and is one of the forest resources of economic interest to the country (GONZÁLEZ-OSORIO \& al [2]) (VLEUT \& al [3]). The increase of urbanizations in arid zones has promoted the development of urban afforestation programs that seek to use specifically with low water requirements to achieve the sustainability of the urban forest (MARTINEZ $\&$ al [4]).

The water deficit is one of the main environmental factors that affects the development of plants, mainly their growth. In plants, low humidity conditions in the soil have had a negative influence on growth and development, affecting their productivity (DAI \& al [5]) (LI \& al [6]) Water stress affects protein synthesis, photosynthesis, respiration, and nucleic acid synthesis, which can be affected by plant performance. In addition to phenotypic variation, the effect of drought on a plant depends on the timing, duration, and severity of stress (CALVOPOLANCO \& al [7]) (DEL POZO \& al [8]). Water stress is one of the most important constraints in the growth and development of plants. Water deficit stress, in particular, is a major problem in agriculture and most crop plants show a higher sensitivity to this kind of stress than any kind of biotic constraint conditions. Crop plant growth and yields are severely impacted by inadequate supply of water, which result in decreased carbon assimilates contents (MANGENA \& al [9]).

Water stress drives important losses in the crop market. Excess or deficit of water produces a cascade of physiological responses that ends-up in decreased production and reduced crop quality. Numerous factors are involved in plant responses to water stress. (SALAZAR $\&$ al [10]). Several studies indicated that the effect of water stress varies according to plants and growth stage (PETROPOULOS \& al [11]). Plants exposure to water stress during the vegetative growth exhibit a decrease in plant height and leaf area dry matter production and number of leaves (ABBASZADEH \& al [12]) (ALIABADI $\&$ al [13]) (NAJLA \& al [14]).

The knowledge of the physiological, cellular, and molecular responses of plants to drought and waterlogging has already allowed great progress in plant breeding; however, few researchers have focused on $O$. pyramidale. The low production and adaptation of forest species is due to environmental factors such as low rainfall that affects plant development. $O$. pyramidale requires a warm and humid climate, the minimum amount of precipitation that it tolerates is around $1500 \mathrm{~mm}$ per year, which represents a great problem in the dry season, where rainfall is scarce, culminating in high mortality. More than $50 \%$ of the raft production in the establishment are affected by the lack of water. Plants under stress are more susceptible to attack by pathogens and pests due to low expressions of resistance mechanisms. The objective of this study was to evaluate the effect of $O$. pyramidale with and without irrigation on morphological, physiological and growth of this plant.

\section{Material and Methods}

All the chemicals used in this study were purchased from Sigma (St. Louis, MO, USA), unless otherwise indicated. All solutions were prepared using water from a Milli-Q Synthesis System (Millipore, Bedford, MA, USA).

\section{Plant material}

The study was carried out at Quevedo State Technical University. O. pyramidale was collected at the experimental station of this University and were stored in optimal conditions. For this study, four random repetitions were carried out in a randomized complete block design. Therefore, 60 plants were used in total in this study (Fig. 1). Half of the plants were put under water deficit imposition by withholding water for ten weeks while another half were maintained in optimal water availability conditions at 15 , 30, 45, 60 and 75 days. All plants were then placed on a bench in outside conditions. A polyethylene cover was also employed in case of rain during the experimental period.
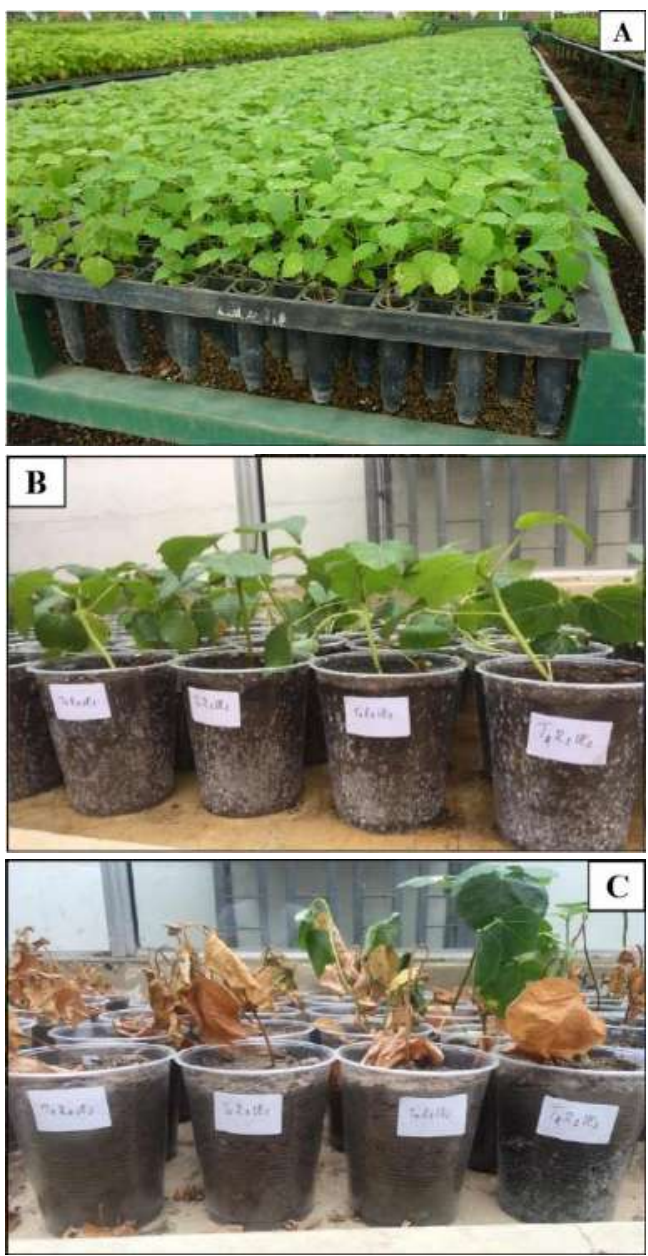

Figure 1. Plants treatment: $\mathbf{A}$ and $\mathbf{B}$ ) with irrigation, C) without irrigation. 


\section{Plant measurements}

Leaves number, shoots number, stem elongation and plant diameter were measured in without irrigation and with irrigation (Control). The evaluations were performed only in the morning. In addition, genomic DNA extractions were performed to validate the presence or absence of genes involved in tolerance to water stress.

\section{Leaves number}

Leaves number of each treatment was evaluated at $15,30,45,60$ and 75 days after being subjected to water deficit, taking as starting point 2-month-old plants. Only functional leaves that did not present pathogen symptoms or wounds caused by mechanical damage were evaluated.

\section{Shoots number}

Shoots number was evaluated periodically every 15 days, the evaluation was carried out in all the plants corresponding to the respective treatment directly without performing interventions such as shoot cutting or removal.

\section{Stoma number}

The morphophysiological condition of the stoma corresponding to each treatment was determined. The opening condition as a result of dehydration or reaction to water stress was also evaluated. Viable leaves that were covered with a thin layer of enamel were used; stoma condition was visualized using a microscope composed of a camera.

\section{Stem diameter and elongation}

Stem diameter and elongation were measured in periods of 15 days from the root base to the last insertion of the leaves, taking as reference the longitudinal advance of each plants evaluated.

\section{DNA extraction}

Genomic DNA was isolated using the DNeasy Plant kit according to the protocol described by the manufacturer. Samples were suspended in $400 \mu \mathrm{L}$ Buffer AP1 and $4 \mu \mathrm{L}$ RNase and were incubated for $10 \mathrm{~min}$ at $65^{\circ} \mathrm{C}$. Then $130 \mu \mathrm{L}$ AP2 was added and incubated for $5 \mathrm{~min}$ on ice. The samples were centrifuged for 5 minutes at $20.000 \mathrm{x} \mathrm{g}$. The supernatants were removed and the pellets were suspended $1.5 \mathrm{~mL}$ of Buffer AP3, $650 \mu \mathrm{L}$ of the mixture was placed into the DNeasy Mini spin column placed in a $2 \mathrm{~mL}$ collection tube and was centrifuged for $1 \mathrm{~min}$ at $\geq 6000 \mathrm{x} \mathrm{g}$, $400 \mu \mathrm{L}$ Buffer AW to the DNeasy Mini spin column, and centrifuge for $2 \mathrm{~min}$ at $20.000 \mathrm{x} \mathrm{g}$. The DNeasy Mini spin column was transferred to a $1.5 \mathrm{~mL}$ or $2 \mathrm{~mL}$ Microcentrifuge tube, and Pipet $100 \mu \mathrm{L}$ Buffer AE directly onto the DNeasy membrane. The sample was Incubated for $5 \mathrm{~min}$ at room temperature, and then centrifuge for $1 \mathrm{~min}$ at $\geq 6000 \mathrm{x}$ g to elute. DNA was evaluated by $1 \%$ agarose gel electrophoresis with ethidium bromide staining. Gels were prepared in $1 \mathrm{X}$ TAE (Tris, sodium acetate, EDTA) buffer containing: $40 \mathrm{mM}$ Tris-base; $1 \mathrm{mM}$ EDTA, $20 \mathrm{mM}$ acetic acid. The gels were analyzed with a digital photodocumentator (E-Gel Imager, Life Technologies) that incorporates a UVP ultraviolet transilluminator and a high-resolution digital camera.

\section{Genomic PCR Screening}

Coding sequence was amplified from genomic DNA by PCR. The probe sequence was PCR amplified using primers (OPA 10: 5'-GTGATCGCAG-3') (A01: 5'CAGGCCCTTC-3') (M 07: 5'-CCGTGACTCA-3'). Transcript amplification and detection were performed using the following thermal profile: $94^{\circ} \mathrm{C}$ for 3 minutes, followed by 40 cycles of $94^{\circ} \mathrm{C}$ for 1 minute, $37^{\circ} \mathrm{C}$ for 2 minutes, $72^{\circ} \mathrm{C}$ for 2 minutes, $72^{\circ} \mathrm{C}$ for 7 minutes and $4{ }^{\circ} \mathrm{C}$ for 5 minutes. The amplification products were separated by electrophoresis (ENDURO TM $300 \mathrm{~V}$ power supply) at 60 volts for 5:30 hours / $\mathrm{min}$, in $2.5 \%$ agarose gel, using TAE $1 \mathrm{x}$ buffer (Tris-base, glacial acetic acid, EDTA $0.5 \mathrm{M}$ ) and photographed with a digital UV light camera (Life Technologies).

\section{Phylogenetic tree}

Phylogenetic tree was determined using the UPGMA method with a branch length of tree = 2.18566002. The tree was drawn to scale, with branch lengths in the same units as the evolutionary distances used to infer the phylogenetic tree. Evolutionary distances were calculated using the Kimura-2 parameters method. The analysis involved 17 nucleotide sequences. The included codon positions were $1^{\text {st }}+2^{\text {nd }}+3^{\text {rd }}+$ non-coding. All positions containing voids and lost data were removed. There was a total of 67 positions in the final data set. Evolutionary analyzes were performed in MEGA6.

\section{Stomatal density}

To determine the stomatal density, epidermal cuts were made to each sample, and it was placed in the center of the engraved area of the Neubauer chamber, to avoid rapid dehydration of the epidermal tissue, $5 \mu \mathrm{L}$ of water was added, then the sample was covered with an object cover, stomatal density was observed using a phase contrast microscope (Carl Zeiss, Jena, Germany) at 400X magnification)

\section{Statistical analysis}

The data were expressed as mean \pm standard deviation (SD) and were analyzed using the statistical software GraphPad Prism ${ }^{\circledR}$, version 6.0 (GraphPad Software, Inc., San Diego, CA, USA). Differences between groups were established using the Tukey's multiple comparison test. The level of significance was set at $\mathrm{P}<0.05$.

\section{Results}

\section{Morphophysiological evaluation of $\boldsymbol{O}$. pyramidale}

\section{Leaves number}

The results showed that there were significant differences between the control and plants without irrigation during evaluation days $(\mathrm{P}<0.05)$. At day 15 of evaluation 
no significant differences $(\mathrm{P}>0.05)$ were observed between the control and plants without irrigation for sheet number. However, at days 30, 45, 60 and 75 leaves number of plants without irrigation were decreased significantly ( $\mathrm{P}<0.05)$ compared to control, showing value 3.3 for day 60 , leaves number for the control was increased with values > 5 (Fig. 2A).

\section{Shoots number}

Shoots number was affected significantly by the evaluation time in both treatment $(\mathrm{P}<0.05)$. No significant differences $(\mathrm{P}>0.05)$ were observed on days 15 and 30 between the control and without irrigation. However, shoots number was decreased $(\mathrm{P}<0.05)$ for the plant without irrigation showing value 0.95 for day 75 , compared to control with 3.7 for the same day (Fig. 2B).

\section{Stomata number}

Regarding stomata number, no significant differences $(\mathrm{P}>0.05)$ were observed between both treatments showing values $>6$ for the plant without irrigation and $>8$ for the control (Fig. 3C).
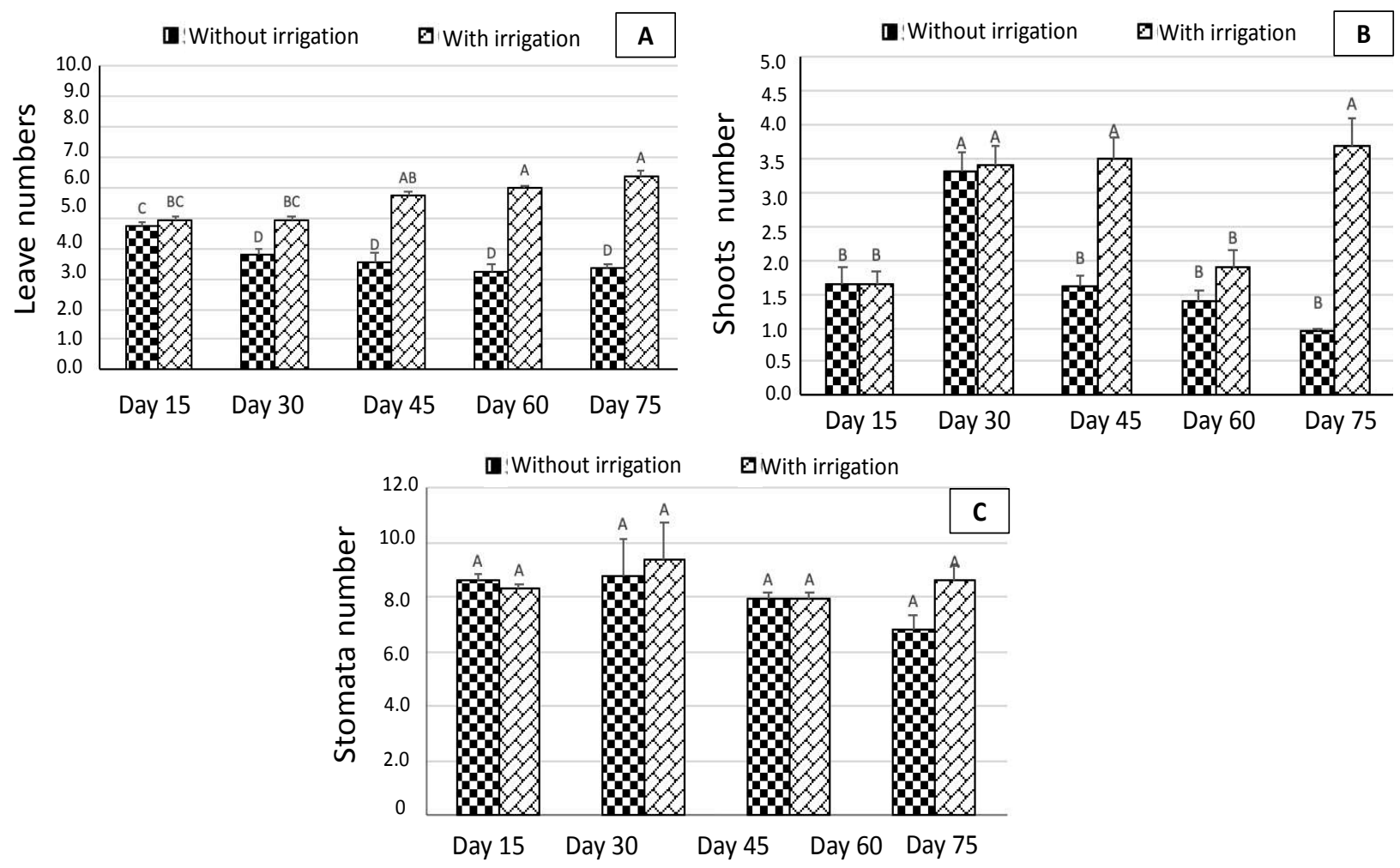

Figure 2. O. pyramidale plants subjected to water deficit. A) Leaves number; B) Shoots number; C) Stomata number. Data are presented as mean \pm SD. A, B, C, D. Different letters indicate statistically significant differences in the same group at different periods of treatment time. Different superscripts indicate different rates $(\mathrm{P}<0.05)$.

\section{Stem elongation}

Stem elongation was affected significantly $(\mathrm{P}<0.05)$ by the time of assessment in the control and plant without irrigation. Stem elongation in the plant without irrigation was decreased, showing a value $12.185 \mathrm{~cm}$ and $21.52 \mathrm{~cm}$ (control) at day 75, respectively (Fig. 3A)

\section{Stem diameter}

Significant differences between the control and plants without irrigation during evaluation days $(\mathrm{P}<0.05)$. At day 15 and 30, no significant differences $(\mathrm{P}>0.05)$ were observed at between the control and plants without irrigation. However, stem diameters for control was increased compared to plants without irrigation presented highest $5 \mathrm{~cm}$ for day 75 (Fig. 3B).

\section{Stomach morphological analysis of $O$. pyramidale}

\section{Length of stomata}

The results showed that stomata length remained high $(>20 \mu \mathrm{m})$ in both treatments during the days of assessment. However, from day 30, 45, 60 of evaluation stomata lengths was significantly decreased $(\mathrm{P}<0.05)$ for plants without irrigation regarding control (Fig. 3C).

\section{Stomata diameter}

The results showed that stomata diameter was decreased during evaluation days in plants without irrigation regarding control, however, no significant differences $(\mathrm{P}>0.05)$ were observed. Significant differences in the control were observed $(\mathrm{P}<0.05)$ during the evaluation days (Fig. 3D). 

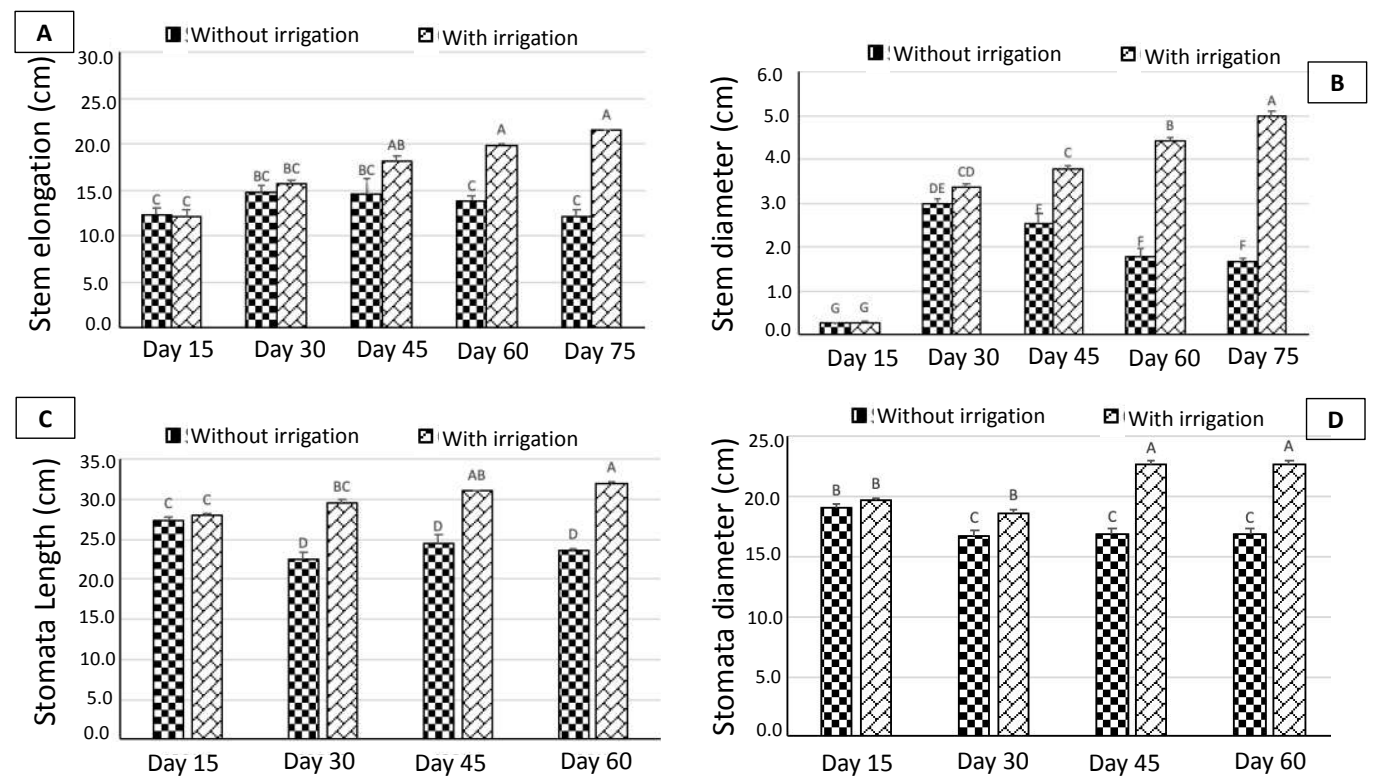

Figure 3. O. pyramidale plants subjected to water deficit. A) Stem elongation; B) Stem diameter; C) Stomata length; D) Stomata diameter. Data are presented as mean \pm SD. A, B, C,D . Different letters indicate statistically significant differences in the same group at different periods of treatment time. Different superscripts indicate different rates $(\mathrm{P}<0.05)$.

\section{Stoma status}

Figure 4 showed stoma status of $O$. pyramidale visualized by microscopy subjected to water deficit: Semiopen stomatal (days 15) (Fig. 4A); Closed and semi-open stomatal (days 30) (Fig. 4B); C) Closed stomatal (days 45) (Fig. 4C); Closed stomatal (days 60) (Fig. 4D). At the stomatal level, there is variation in the morpho-physical characteristics in plants with water deficit, after 30 days the length and diameter of stomata is less with 22.50 and $16.79 \mu \mathrm{m}$, while a plant with constant irrigation the length is significantly higher showing values of 29.55 and $18.68 \mu \mathrm{m}$, respectively.

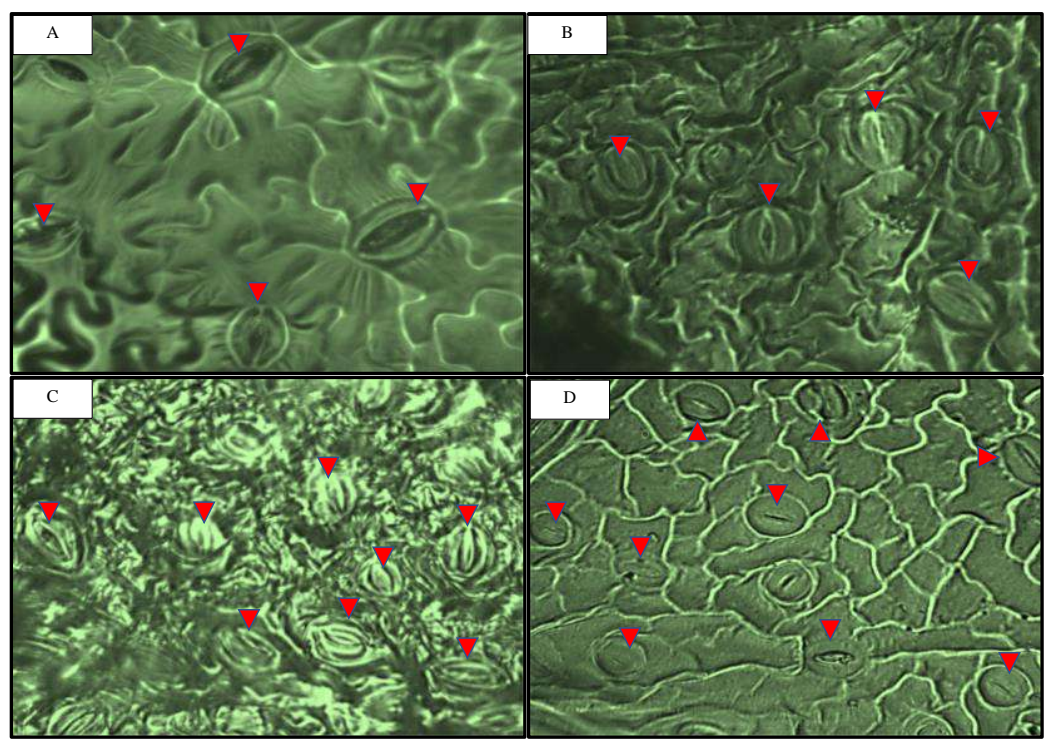

Figure 4. Leaves visualized by microscopy: A) Semi-open stomatal (days 15); B) Closed and semi-open stomatal (days 30); C) Closed stomatal (days 45); D) Closed stomatal (days 60).

\section{DNA Extraction by ERIC-PCR and RAPD}

The extraction of DAN was realized for evidencing the possible similarities among the plants using 8 $O$. pyramidale. The results showed identical bands, both in number and size as shown in Fig. 5A. However, Random
Amplified Polymorphic DNA (RAPD) technique and ERIC-PCR increased the resemblances degree amongst between the plants. It has been found that the largest amplified product was $1500 \mathrm{bp}$ and the smallest was only 100 bp (Fig. 5B and C). 

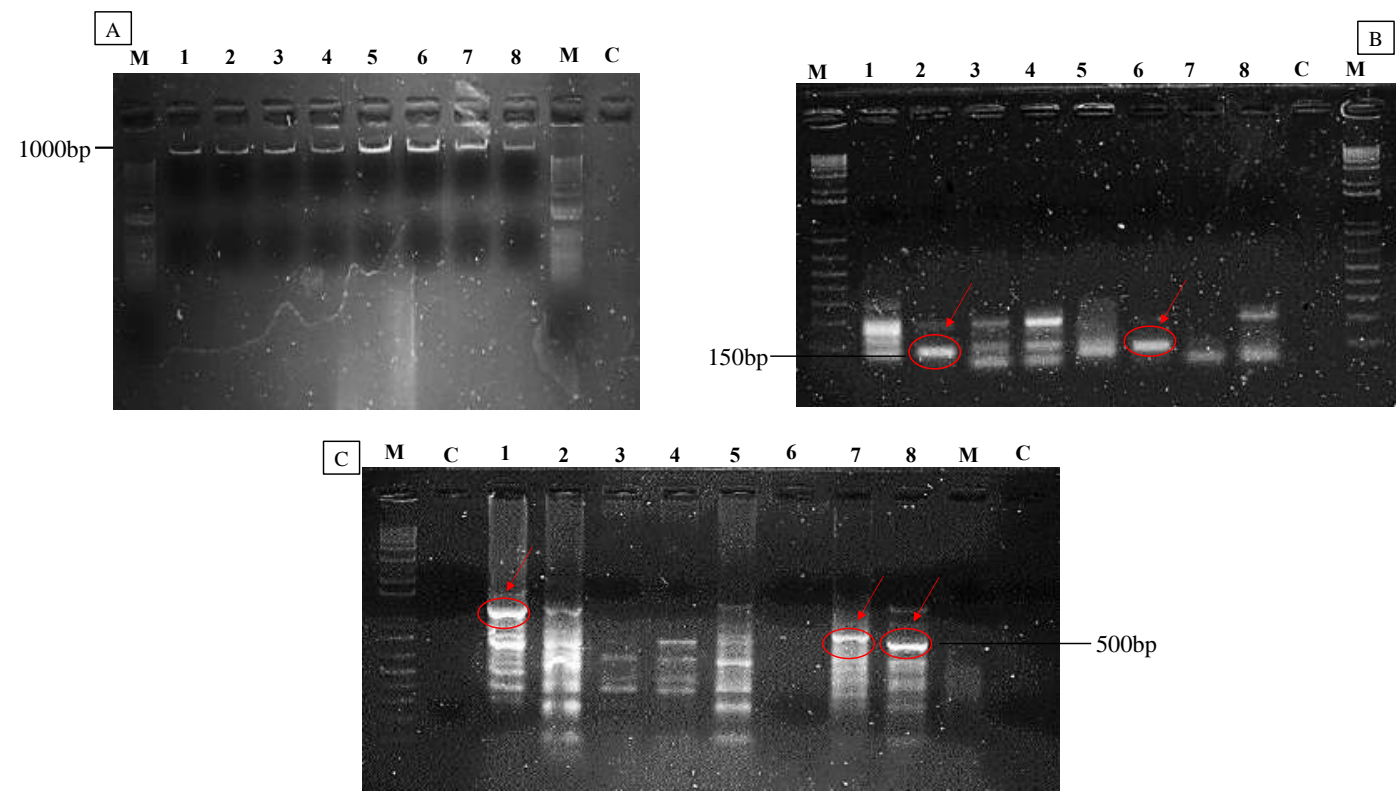

Figure 5. A) Genomic DNA identification of $O$. pyramidale, B) by ERIC-PCR, C) by RAPD. The number of scorable bands for responding primers ranging from 1 to 11 with an average of four bands, ranging from the largest amplified product, $1500 \mathrm{bp}$ and the smaller, $100 \mathrm{bp}$. While 1-2 (15 days) 3-4 (30 days), 5-6 (45 days), 7-8 (60 days), M (molecular weight markers) and Control.

\section{Phylogenetic grouping of $O$. pyramidale}

The phylogenetic tree obtained by ERIC-PCR was performed according to the Maximum Composite Likelihood model, formed by two main groups (I and II) and four subgroups (A, B, C, and D). Group I, brought together a sub group (A) consisting of Balsa 1, Balsa 5, Balsa 4 and Balsa 8, and subgroup (B) consisting by Balsa 2 and Balsa 3 plants, all these plants belonging to the treatments of water deficit. Group II, brought together the sub group (C) consisting of the Balsa 6 and Balsa 7 plants, belonging to the water deficit treatments, there is also the sub group (D) made up of the Balsa 9 plants, which was as a control (Fig. 6a). The phylogenetic tree obtained by RAPDs also presented two groups (I and II).

Group I brought together a sub group (A), consisting of the Balsa 2, 3, 8, 9, 6 plants and sub group (B) consisting of the Balsa 5 plants, all of these plants belonging to the water deficit treatments at the exception of Balsa 9 which was as a control. Group II brought together a sub group (C) consisting of the Balsa 4 plant and sub group (D) consisting of the Balsa 10, 1 and 7 plants, also belonging to the water deficit treatments (Fig. 6b).
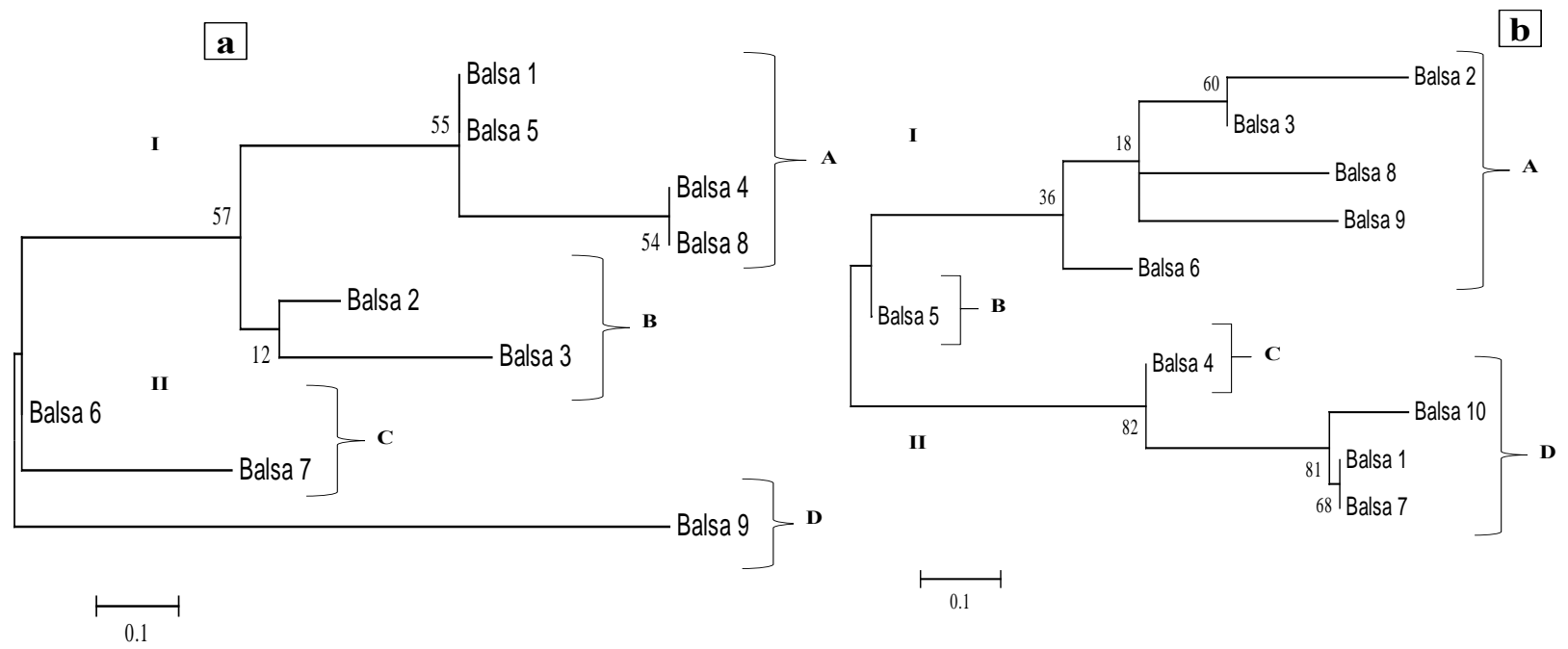

Figure 6. Phylogenetic clustering of $O$. pyramidale by ERIC-PCR (a) and RAPD (b) constructed from plant DNA. The evolutionary distance was deduced using the Neighbor-Joining method. The phylogenetic tree was constructed using Maximum Composite Likelihood. The numbers represent percentages of bootstrap. 


\section{Discussion}

CHEN \& al ([15]) have reported that a plant adapts to prolonged drought stress via changes in the root system morphological conformation, photosynthetic product allocation to above ground, and underground portions, and more efficient utilization of the limited soil water. JALEEL \& al ([16]) have reported that drought stress is a very important limiting factor during early seedling growth and establishment.

It affects both elongation and expansion growth. Water-deficit stress is considered as one of the most important growth-limiting factors that decrease plant growth. Injury of plants takes place under water shortage at any vegetative growth stage (TÁTRAI \& al [17]). Results from our study indicate that water-deficit stress reduced the growth of $O$. pyramidale. Several studies have reported similar effects caused by water-deficit stress (LENHARD \& al [18]) (AVRELLA \& al [19]). In this study, stem elongation in $O$. pyramidal without irrigation was decreased, showing a value $12.185 \mathrm{~cm}$ compared to control $21.52 \mathrm{~cm}$ at day 75. A similar situation was reported by AVRELLA \& al ([19]) for stem elongation $O$. pyramidal showing a value $29.59 \mathrm{~cm}$ with irrigation for 35 days and $53.96 \mathrm{~cm}$ at 70 days. One explanation of this reduction could be that plants grown with constant irrigation of water, it has more capacity to attract nutrients from the soil. The results obtained for height and diameter throughout the time of conducting the experiment in high levels of water deficiency, is the sensitivity of the physiological process to water deficit, which is a strategy of the plant in dealing with the range of variation of water availability.

AVRELLA \& al ([19]) reported that some plants show a water stress adaptive mechanism by restricting their growth while water shortages in the rhizosphere persists. Accordingly, we might suggest that $O$. pyramidal plants conserve their growth and sacrifice the vegetative development for gaining a long-term survival under drought stress condition. In our study, the plants subjected to more than 45 days of water deficit showed up to $50 \%$ less leaf area, which means that their morpho-physical characteristics were altered. Well-developed root system is considered as a strategy for desiccation avoidance in natural vegetation. Morphological root components play a major role in root hydraulics that can reflect different responses to drought stress (BRAMLEY \& al [20]).

Physiologically, the water content is probably the most appropriate for a plant CALVO-POLANCO \& al [7]) (KOLENC \& al [22]). Our results showed that significant differences between the control and plants without irrigation during evaluation days in all parameters evaluated. Several studies have demonstrated that species of high-resource environments take advantage of the water supply increase, while species adapted to stress are less plastic. Severe stress caused reductions in length, number of leaves, suggesting that $O$. pyramidale is vulnerable to water stress.
Water stress, in general, leads to the accumulation of solutes in the cytoplasm and in the vacuole of plant cells, thus allowing the cells to maintain the pressure even at a low water potential. This positive pressure is essential for plant growth, as well as increasing the mechanical stiffness of cells and tissues. Studies show that plants subjected to severe water deficit, invest more in root elongation than in the shoot, which increases the potential to absorb water from the deeper layers of the soil profile (SOARES \& al [23]) (VENIER \& al [24]). According to these studies, to achieve a high level of budding success, plant materials should not be watered deficit during the bidding period. In general, the results obtained in this study suggest that $O$. pyramidale can be used in management plans and restoration of areas, as well as its commercial production in areas with water stress.

\section{Conclusions}

In this present study, it can be concluded that water deficit affected plant growth. The water deficit resulted in reduction in growth parameters by decreasing relative shoot length and diameter of the plant. The effect of water deficit conditions was more visible in the plant without irrigation compared to control. This should be taken into account where the water deficit is a limiting factor in $O$. pyramidale nursery and orchards.

According to the analysis of morphological and physiological, it is concluded that $O$. pyramidale plants were not able to tolerate conditions of low water availability. A further detailed study is also needed to elucidate the underlying biochemical processes and anatomical and genetic parameters which are responsible for differential responses of $O$. pyramidale.

\section{Acknowledgments}

This research was supported by Universidad Técnica Estatal de Quevedo, Quevedo, Ecuador and University of La Frontera/Postdoctoral (KD) 2019.

\section{References}

1. C.E.B.C. SEABRA, A. OSIECKA, C.A.F. TUCCI, P.J. MINOGUE, B.F.F. PEREIRA, P.C. ANDERSEN. Influence of phosphorus limitations on the growth, nutrient partitioning, and physiology of mahogany (Swietenia macrophylla King) seedlings. Journal of Plant Nutrition, 358-370 (2017).

2. B.G. GONZÁLEZ OSORIO, X.C. MOLINA, E.T. NAVARRETE, C.S. FONSECA, L.S. OCHOA. Caracterización del cultivo de balsa (Ochroma pyramidale) en la Provincia de los Ríos-Ecuador. Revista Ciencia y Tecnología, 3, 7-11 (2010)

3. I. VLEUT, S.I. LEVY-TACHER, W.F.D.E. BOER, J. GALINDO-GONZALEZ, N. RAMIREZ-MARCIAL. Can a fast growing early-successional tree (Ochroma pyramidale) accelerate forest succession? Journal of Tropical Ecology, 29, 173-180 (2013). 
4. C.F. MARTINEZ, J.B. CAVAGNARO, F.A. ROIGJUNENT, M.A. CANTÓN. Respuesta al déficit hídrico en el crecimiento de forestales del bosque urbano de Mendoza. Análisis comparativo en árboles jóvenes. Revista de la Facultad de Ciencias Agrarias, 45 (2013).

5. X.D. DAI, X.Z. XU, C.C. ZHU, Y.F. YANG, C.Y. WANG, X.P. YANG. Seeding stage response to different water availability and drought resistance evaluation of foxtail millet. Crops, 1, 140-143 (2016).

6. S.J. LI, L. CHEN, S.D. PENG, S.W. CHEN, Q.F. WANG, L.B. LIN. Screening of drought-tolerant Brassica napus L. varieties and analysis on their physiologic and biochemical variations under drought stress. Agric. Sci. Tech, 4, 596-604 (2014).

7. M. CALVO-POLANCO, I. SÁNCHEZ-CASTRO, M. CANTOS, J.L. GARCÍA, R. AZCÓN, J.M. RUIZ-LOZANO, R. AROCA. Effects of different arbuscular mycorrhizal fungal backgrounds and soils on olive plants growth and water relation properties under well-watered and drought conditions. Plant, Cell \& Environment, 39, 2498-2514 (2016).

8. A. DEL POZO, A. YÁÑEZ, I.A. MATUS, G. TAPIA, D. CASTILLO, L. SANCHEZ-JARDÓN, J.L. ARAUS. Physiological Traits Associated with Wheat Yield Potential and Performance under Water-Stress in a Mediterranean Environment. Frontiers in Plant Science. Doi:10.3389/fpls.2016.0098

9. P. MANGENA, A. THANGWANA. The Role of Plant Gene Transformation in Oilseed Crop Improvement in Agriculture. Journal of Biotechnology and Bioengineering, 2(3), 19-25 (2018).

10. C. SALAZAR, C. HERNANDEZ, M.T. PINO. Plant water stress: Associations between ethylene and abscisic acid response. Chilean Journal of Agricultural Research, 75, 71-79 (2015).

11. S.A. PETROPOUlOS, D. DAFERERA, M.G. POLISSIOU, H.C. PASSAM. The effect of water deficit stress on the growth, yield and composition of essential oils of parsley. Scientia Horticulturae, 115, 393-397 (2008).

12. B. ABBASZADEH, A.E. SHARIFI, M.R. ARDAKANI, F.H. ALIABADI. Effect of drought stress on quantitative and qualitative of mint. Abstracts Book of $5^{\text {th }}$ International Crop Science Congress \& Exhibition. Korea, pp 23. 2008.

13. F.H. ALIABADI, S.A.R. VALADABADI, J. DANESHIAN, M.A. KHALVATI. Evaluation changing of essential oil of balm (Melissa officinalis L.) under water deficit stress conditions. J Med Plant Res, 3, 329-33 9 (2009).

14. S. NAJLA, R. SANOUBAR, R. MURSHED. Morphological and biochemical changes in two parsley varieties upon water stress. Physiology and Molecular Biology of Plants, 18, 133-139 (2012).

15. L. CHEN, S.F. WANG, R.L. LIU, H. WANG. Changes of root morphology and rhizosphere processes of wheat under different phosphate supply. Plant Nutr. Fertil. Sci, 2, 324-331(2012).

16. C.A. JALEEL, P. MANIVANNAN, A. WHID, M. FAROOQ, H.J. AL-JUBURI, R. SOMASUNDARAM, R. PANNEERSELVAM. Drought stress in plants: a review on morphological characteristics and pigments composition. Int. J. Agric. Biol, 11, 100-105 (2009).

17. Z.A. TÁtrai, R. SANOUBAR, Z. PLUHÁR, S. MANCARELLA, F. ORSINI, G. GIANQUINTO. Morphological and Physiological Plant Responses to Drought Stress in Thymus citriodorus. International Journal of Agronomy, 10, 1-8 (2016).

18. N.R. LENHARD, S.P.Q. SCALON, J.O. NOVELINO. Crescimento inicial de plantines de pau ferro (Caesalpinia ferrea Mart. ex Tul. var. leiostachya Benth.) sob diferentes regimes hídricos. Ciência e Agrotecnologia, 34, 870-877 (2010).

19. E.D. AVRELLA, L.P. PAIMA, A.R. EDGARRIVERA, M. MAZZURANA, G. SCHAFER, C.S. FIOR. Initial development of Mimosa scabrella seedlings under different water regimes. BOSQUE, 40(3), 277-285 (2019).

20. H. BRAMLEY, N.C. TURNER, D.W. TURNER, S.D. TYERMAN. Roles of morphology, anatomy, and aquaporins in determining contrasting hydraulic behavior of roots. Plant Physiology, 150, 348-364 (2009).

21. M. CALVO-POLANCO, B. SÁNCHEZ-ROMERA, R. AROCA. Exploring the use of recombinant inbred lines in combination with beneficial microbial inoculants (AM fungus and PGPR) to improve drought stress tolerance in tomato. Environ Exp Bot, 131, 47-57 (2016).

22. Z. KOLENC, D. VODNIK, S. MANDELC. Hop (Humulus lupulus L.) response mechanisms in drought stress: proteomic analysis with physiology. Plant Physiol Biochem, 105, 67-78 (2016).

23. L.A.A. SOARES, M.E.B. BRITO, P.D. FERNANDES, G.S. LIMA, W.S. SOARES FILHO, E.S. OLIVEIRA. Growth of combinations of scion and citrus rootstocks under water stress in greenhouse. Revista Brasileira de Engenharia Agrícola e Ambiental, 19, 211-217 (2015).

24. P. VENIER, M. CABIDO, A. MANGEAUD, G. FUNES. Seedlings growth and survival of five Acacia (Fabaceae) species that coexists in neotropical semiarid forests of Argentina, under different light and water availability conditions. Revista de Biologia Tropical, 61, 501-514 (2013). 